\title{
当院における患者の歯科に対する意識調査
}

\author{
池田育代, 貞光謙一郎*1, 綾田知子, 星山正美, 片芝菜穗子, 山本賢彦
}

\section{A Questionnaire Survey in Dentistry of Patients in Our Clinic}

Ikuyo Ikeda, Kenichirou Sadamitsu *1, Tomoko Ayata,

Masami Hoshiyama, Naoko Katashiba, Yoshihiko Yamamoto

In order to offer better medical services and enrich people's lives, those employed in medical services need to consider not just technical aspects but also how to offer customer-friendly services. Therefore, to gain a better understanding of patients' view, we have conducted a questionnaire-based survey of 80 patients in our clinic.

The survey showed that although patients take great interest in dental services, they have insufficient experience of oral health education; therefore we examined the results with this in mind.

よりよい医療を提供し人々の暮らしを豊かにしていくためには, 医療従事者の技術の研 鑚だけでなく, 患者側の納得のうえで双方が満足のいく医療を実現していく必要性がある. そこで今回われわれは，当医院で実際に歯科医療サービスを受けた患者 80 名を対象に， 歯科医療，歯科医院に対するアンケート調査を実施した。

その結果, 患者側の歯科医療に対する関心度の高さとは反対に日々の生活に浸透してい ない口腔衛生教育の現状を当医院での背景として把握したうえで検討を行った。

Key words：アンケート調査 A Questionnaire Survey, 予防歯科 Preventive Dentistry, ブラッシング Brushing 


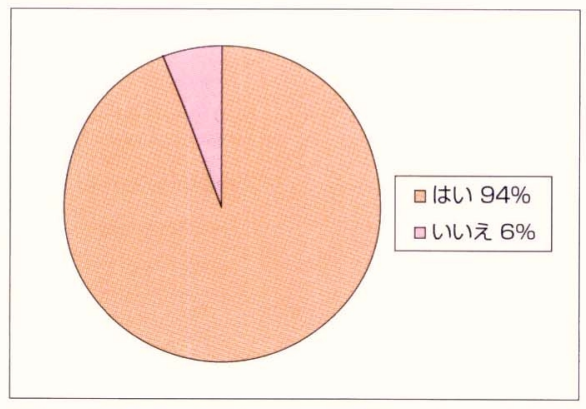

図 1 口腔内の関心度について.

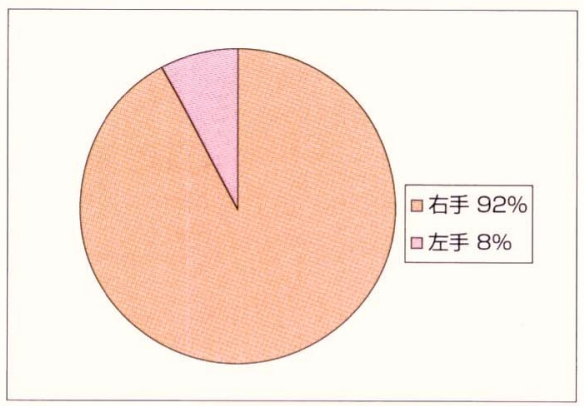

図 4 ブラッシング時の利き手について.

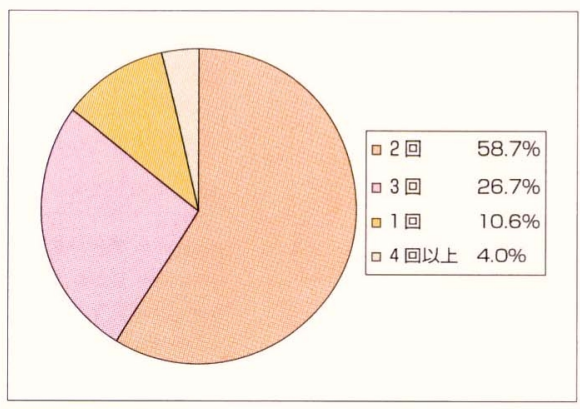

図2 一日のブラッシングの回数について.

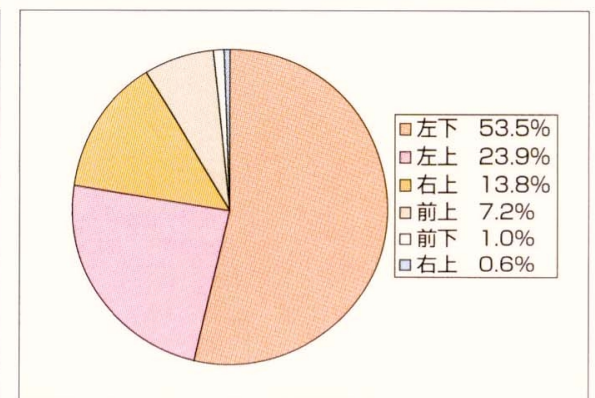

図 5 磨き始めの部位について．

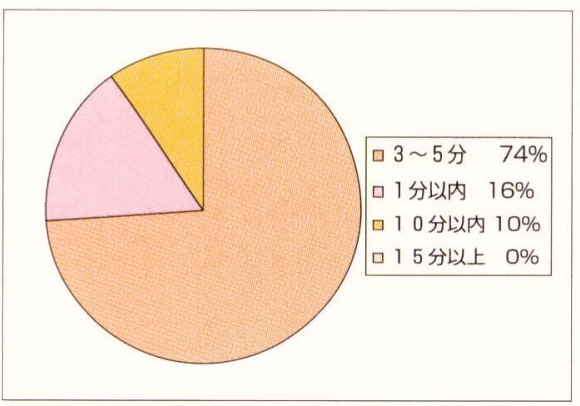

図３１回のブラッシング時間について.

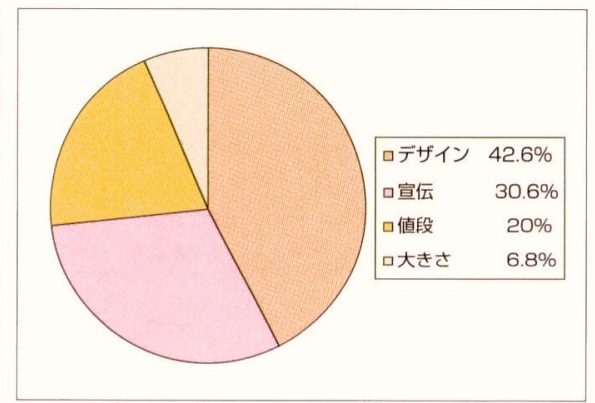

図6 歯ブラシの選択基準について.

\section{緒言}

近年, 日本では医療施設が乱立し, 患者側が医療を選ぶ 時代へと変化を遂げている。われわれ医療従事者は, 技術 の研鑚だけでなく，どのような形で医療を提供し，どのよ うに経営すれば，患者側の納得のうえで双方が満足のいく 医療を確立できるのかを考えなければならない。しかしな がら，患者が歯科医療をどのように考え，望んでいるのか を完全に理解することは難しい。 そこで今回，われわれは 当医院で実際に歯科医療サービスを受けた患者を対象に, 歯科医院に対する要望および歯科予防，患者の歯科に対す る意識や知識を把握するため, アンケート調査を実施した。 その結果，若干の知見を得たので報告する。

\section{方法}

被験者は，平成 15 年 1 月 6 日から平成 15 年 2 月 20 日ま でに当医院を受診した 15 歳から 86 歳の男性 25 名, 女性 55 名の合計 80 名を無作為に抽出し，アンケートの主旨を 説明したうえで協力が得られた患者を対象とした。アン ケートは自己記入式の質問票を作成し，対象者に配布，回 収後解答を分析した。

質問内容は無記名で，年齢・職業の基本事項に加え， 「ブラッシングについて」と「歯科医院について」の2つ
の内容を詳細に設問した。 口腔内の関心・ブラッシング状 況・歯ブラシ・歯磨剂・清掃補助用具に関する事項・キシ リトール製品の使用の有無. 当歯科医院までの交通手段・ 所要時間・選んだ理由・待ち時間の満足度・治療につい て・医院の清掃状態・スタッフの対応について, また歯科 医院を選ぶ基準・簡単な歯に対する知識などを問う質問を 設けた。

\section{結果}

アンケートの回收率は $100 \%$ で, 内訳は男性 $31.3 \%$, 女 性 $68.7 \%$ で, 平均年齢は 44.9 歳であった。職種構成につ いては主婦層がもっとも多く $41.6 \%$, ついで会社員の $27 \%$ あったた。た，患者自身の川腔内への関心につい て質問したところ，関心のある人が $94 \%$ と高い割合を示 した(図1).

ブラッシングについての設問内容と結果を以下に示す. 1 日のブラッシングの回数は, 1 日 2 回が $58.7 \%$ ともと も多く，次いで 3 回の $26.7 \%$ あっあた (図2). 1 回のブ ラッシングにかける時間は 3〜 5 分という人が $74 \%$ と もっとも多いが，早い人では1 分以内というのが $16 \%$ も いた(図 3). ブラッシング時の利き手については, 右手 $92 \%$, 左手 $8 \%$ であり, どこから磨き始めるかについては, 左下 $53.5 \%$, 左上 $23.9 \%$ の順で多く, 利き手が右手とい う人が $92 \%$ 古めることから, 右利きの人は左下からブ 


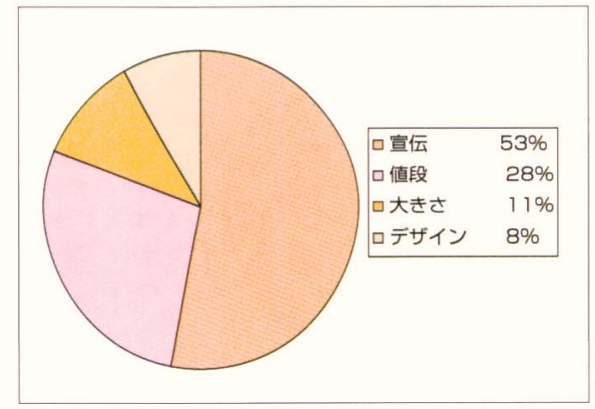

図 7 歯磨剤の選択基準について.

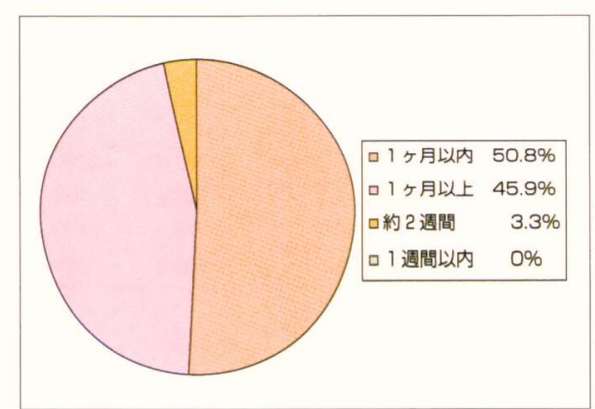

図 10 歯ブラシを買い換える期間について.

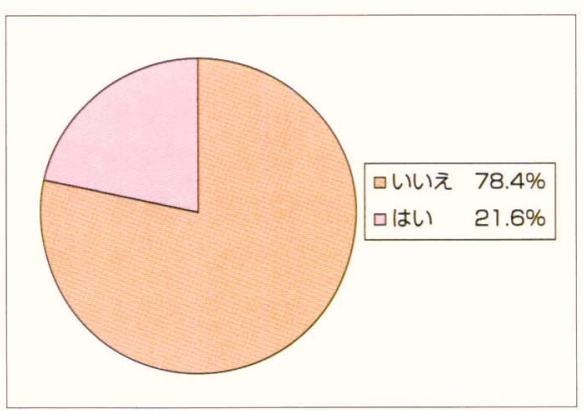

図 13 手用歯ブラシ以外の歯ブラシの使用に ついて.

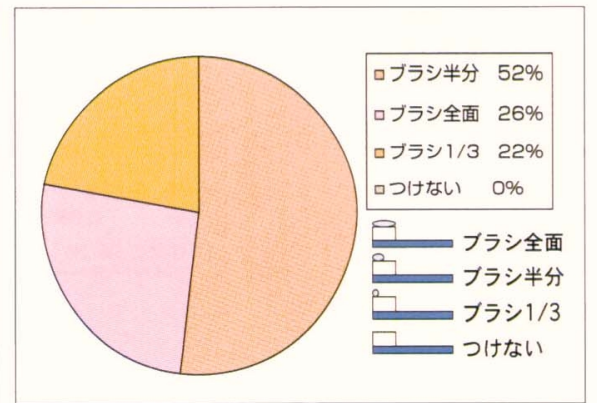

図81回の歯磨剤の量について.

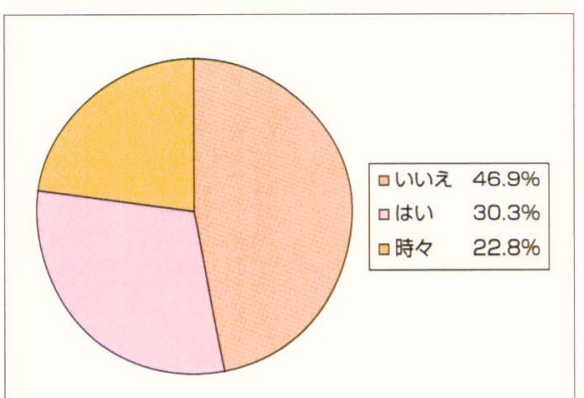

図 11 歯間ブラシの使用度について.

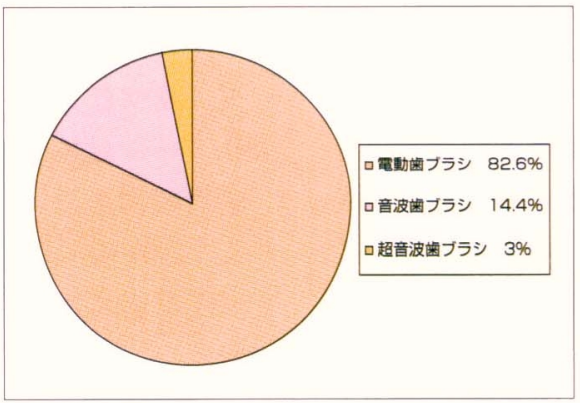

図 14 手用歯ブラシ以外の認知度について.

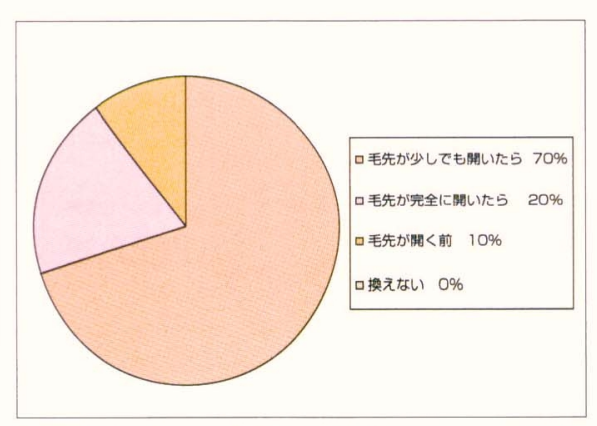

図9歯ブラシを買い換える目安について.

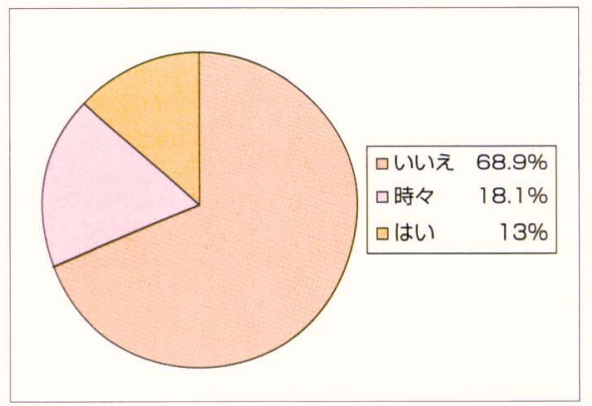

図 12 フロスの使用度について

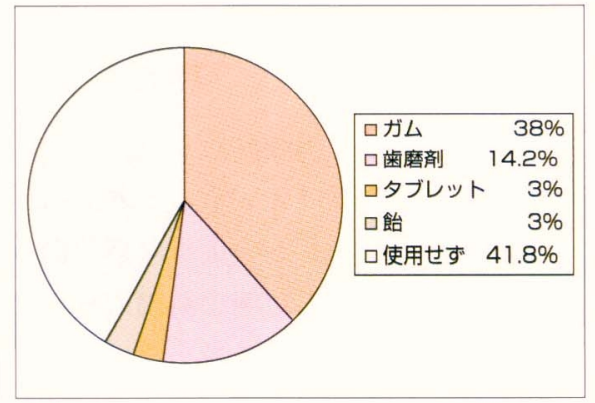

図 15 キシリトール製品について.
ラシを当てるアプローチが多いことが示唆された(図 4, 5).

どんな歯ブラシを使用しているかの設問には, 電動歯ブ ラシ・システマ・GUM・やまぎりカット・PCクリニ カ・リーチ・ソニッケア・DOクリア・豚毛など，市販さ れている歯ブラシの種類の多さを裏付ける結果となった. また同様に，どんな歯磨剤を使用しているかの設問には， クリアクリーン・デンター・GUM ・ ライオン・アパガー ド・塩入り・アクアフレッシュ・PCクリニカ・ホワイ ト\&ホワイト・アセスなど, こちらも数十種類の製品が挙 げられた。

歯ブラシを選ぶ基準については，「デザインで選ぶ」が $42.6 \%$ で，歯磨剤を選ぶ基準は「宣伝で選ぶ」が $53 \%$ \%
あった(図6，7）。しかし，歯ブラシも歯磨剂も使用して いるものに統一性はなく，「何を使ったらよいのかわから ない」と言う人が多いようである。また歯磨凨にしては， 「宣伝を見て選ぶ」というのが多く，宣伝の重要さが伺え る。歯磨剤を付ける量は,「歯ブラシの半分以上つける」 人が $52 \%$ と多く，次いで「歯ブラシ全面につける」が $26 \%$ ，つけない人は０\%であった(図8).ささらに歯ブラ シを換える目安については，換えないという人は一人もお らず，「毛先が開いたら換える」という人がほとんどで， そのなかでも「毛先が少しでも開いたら換える」という意 見が70\%ともっとも多かった。㐘ブラシを換える期間は 過半数以上の $50.8 \%$ ○が 1 ケ月以内に歯ブラシを交換す る結果となった (図9、10)。歯間ブラシの使用度につい 


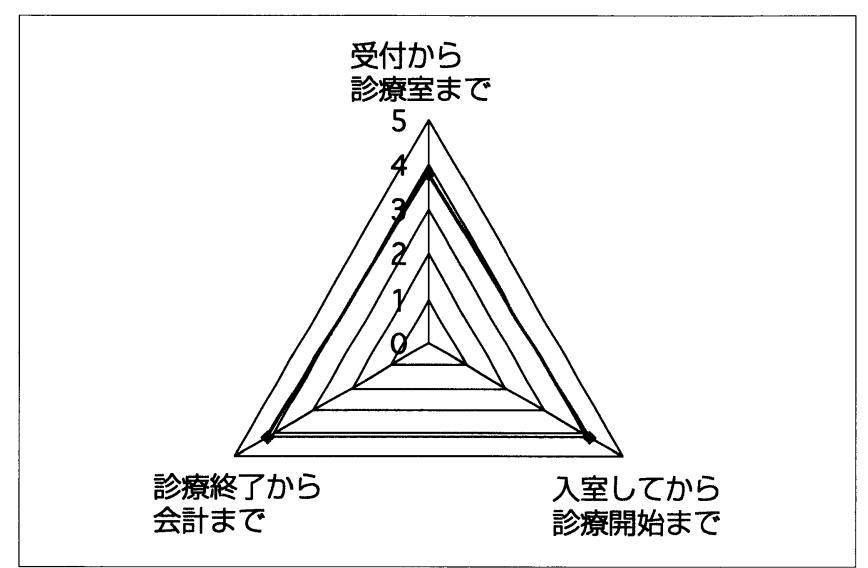

図 16 待ち時間について.

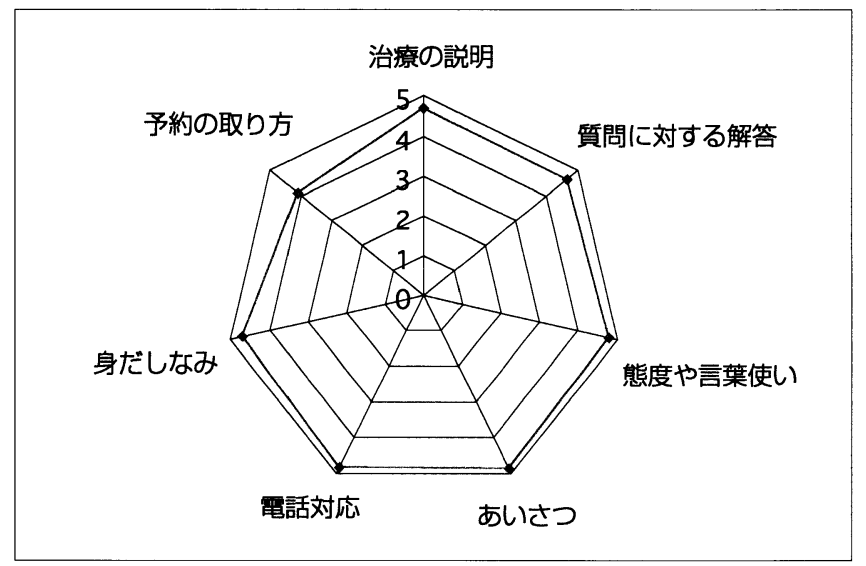

図18 スタッフについて.

ては，全体の $52.3 \%$ と半数以上の人が歯間ブラシを使用し ていた(図１１）。フフスの使用度については，歯間ブラシ に比べてフロスの使用は $21.1 \%$ と低かった(図 12). 手用 ブラシ以外の歯ブラシを使用している人は， $21.6 \%$ であっ た（図 13）。手用ブラシの歯ブラシで知っているものにつ いては，電動歯ブラシが $82.6 \%$ と高い認知度を示した (図 14 )。キシリトール製品を使用している人は全体の $58.2 \%$ \%市，もっとも多いのはガムの $38 \%$ で，歯磨郕 は $14.2 \%$ \%った(図 15).

続いて, 歯科医院の環境についてのアンケート結果を示 す. 地域分布については $91 \%$ \% 当歯科医院の近辺 (奈良市 内）であった．所要時間は 10 分以内が $68 \%, 10 \sim 20$ 分が $20 \%$ であった. 交通手段として徒歩が半数以上の $55 \%$ で 自動車が $26 \%$ \%゙った．当歯科医院を選んだ理由は「自 宅から近い」というのが半数以上を占めて $66 \%$ ，「知人の 紹介」 $28 \%$ ，「家族が通っている」，「広告を見て」に続く 結果となった．待ち時間については $1 \sim 5$ 点評価での平均 スコアを図 16 に示す。待ち時間は「受付から診療室まで」

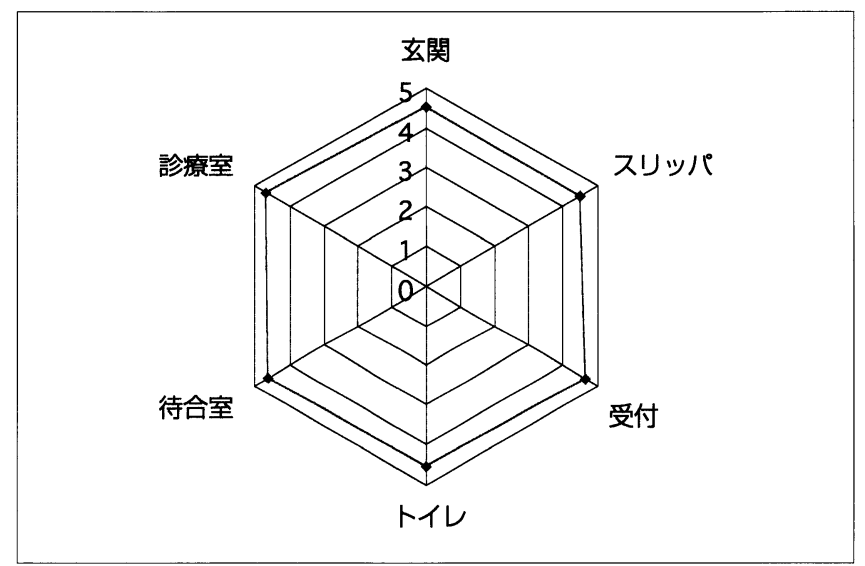

図 17 清掃状態について.

は 3.79 点,「入室してから診療開始まで」は 4.16 点,「診 療終了から会計まで」は4.15点であった．清掃状態につい ては, 図 17 に示す. 玄関, スリッパ，受付，トイレ，待 合室, 診療室すべてにおいて, 清掃状態は平均 4.5 以上で 高得点であった。 スタッフについては, 図 18 に示す結果 となり，スタッフの対応も認めてもらい，す心゙ての項目で 高得点を得ることができた。歯科医院を選ぶ基準について は，7 項目を優先順位で並べてもらった結果，上手 $\rightarrow$ 自宅

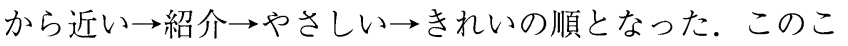
とから，初診時に歯科医院を選ぶ理由としては「自宅から 近い」ということから選ばれるが，後に通院する際は「上 手」というのが一番の選択基準であると考えられる。つま り単純に歯科医院の基準としては，「上手」が一番の選択 基準ということになる.

\section{考察}

回答者の内訳は主婦層が一番多く, 次に会社員に続くが 学生が $2 \%$ と少ない結果となり, 若年者の歯科への意識が 低いのではないかと考えられる.

ブラッシングについては，利き手が右手というのが大半 を占めて打り, 半数の人が左下からのアプローチになって いることから，利き手と逆のほうが磨きやすいようである と推察される。また, 厚生省の統計によると, S.44 年の 「毎日歯を磨く」という人は $79.68 \%$ ，そのうち 1 回が $62.79 \%$ ， 2 回が $15.11 \%$ であったのが，S.56 年になると 「毎日磨く」人は $90.51 \%$ になり，そのうち 1 回が $46.4 \%$ ， 2 回が 36.57 \%になった ${ }^{1}$. 近年については, 今回のアン ケートの結果, 毎日磨く人は, 当歯科医院来院者に関して は $100 \%$ で，2回以上磨く人は $99.4 \%$ と，朝・晚の歯磨き は習慣付けられているようである。ブラッシングにかける 時間は $3 \sim 5$ 分がもっとも多かったが，現在正しい歯磨き 
方といわれる方法のどれを用いても，またその方法できち んとトレーニングを受けた人でもこの時間では不十分と考 える，年齢によっても差はあるが，最低でも 10 分はかか るのではないだろうか.

「どんな歯ブラシを使用しているのか」という質問には 統一性がなく，「何を使ったらよいのかわからない」と言 う人が多い，歯ブラシを選ぶ基準として，デザインが $42.6 \%$ \%っっをも多いが，そのデザインを選抜する方法に ついては考える余地がある，歯磨剤にしても，結果より宣 伝の重要さが伺える. 歯磨剤を付けないドライブラッシン グに比べて, 研磨剤入りの歯磨剤をつけて磨くほうが色素 除去に有効であるうえ，プラーク除去効果も高く，再付着 も抑制さされることがわかっている．また発泡剤そのもの にも抗菌作用があると証明されている ${ }^{2}$. しかし，清掃道 具が直接接触してこすりとるということが基本であり，歯 磨郕に頼るということではない，また，歯磨郕の清掃力が 高いということは，歯に対する研磨性も高く，磨けていな いのに，発泡剂によって「磨けた」と錯覚しやすい，その ため，歯ブラシに半分または半分以上付ける人が 78 \% と 多いのではないだろうか.

新しく歯ブラシを取り換える時期の目安は，毛先が開い てきたときである．新しいものに比べて開いたものは污れ の取れ方の効率が下がるという意識は根付いているので, 歯科衛生士はそのひらいてくる時期や開き方を見抜いて指 導していく必要がある.

口腔内の関心は, 歯ブラシを換える目安や期間 - 磨くと きに注意していることなど, かなり高いように考えられる。 しかし関心はあるものの, 補助器具の質問に対して歯間ブ ラシの使用も半数の人が使用しておらず，フロスに関して は，フロスの意味がわからずアンケート回答時に質問され るというのが現状であった。

手用以外の歯ブラシについての設問は，今までは決定的 な清掃効果の証明はなく, 清掃道具が直接接触して擦り取 るというメカニズムを期待したものが主流であったが，最 近, 電動歯ブラシや音波ブラシ, 超音波ブラシといったさ まざまな商品が開発され，大きく宣伝されている，清掃効 果も上がっており, 関心もあるものの, 使用頻度の少なさ には驚かされた。

「甘いものを食べたらむし歯になる」「食べたらすぐに 歯を磨かなくてはならない」という日常の欲望を否定した り, 強制的な行為に対して, 日常生活に取り入れやすい歯 によい食品としてキシリトールガムが市場に定着してい る。しかし，実際に使用されているのはガムでも $38 \%$ と 低く, 歯科医療関係者からの十分な知識の供給がないから
ではないかと考えられる。

歯科医院の環境についての設問からは, 患者の歯科医院 を選ぶ基準はやはり多くある歯科医院から，技術云々より もまず近いところ・通院しやすい場所であるというのが最 優先で決められているようである. 交通手段は徒歩の次に 自動車で通院できるということで, 駐車場の有無・数も大 切な要素であるといえる。 また，医院としては近いところ， 通いやすいところという選択よりも知人の紹介が半数以上 を占めてこそ, 安定した経営が考えられる. 待ち時間の満 足度についてのアンケートでは, 平均 4 点を上回っている が，受付から診療室までの時間のスコアが 3.79 と低くなっ て扔り，少し不満足ということだった。清掃状態はやはり 清潔感は大切なので清掃には時間をかけて行っている。そ のため平均 4.57 という高得点を得ることができた。 スタッ フについては, 患者の希望する日の予約を取ることが難し く, 少し延ばしてもらうことが多いため, 他の項目に比較 して少しスコアが落ちる. しかし，対応に関しては，つね にコミュニケーションをはかり患者に少しでも気分よく接 することを心掛けているため, 高得点を得ることができた.

\section{結論}

アンケートの結果から，患者の歯に対する知識・意識は 非常に高いことが明らかになった。しかし，歯ブラシや歯 磨剤を選ぶ基準も，結局何を選んだらよいのかわからない というのが現状で，患者のほとんどが自分に合っているも のを意識的に選んで購入しているわけではなく, 特に理由 もなく選択し使用しているようである。つまり知識・意識 は高いものの, 歯ブラシ・歯磨剤・清掃補助用具に関して は認識が低い。

現在手用歯ブラシに加え，電動歯ブラシや音波ブラシ， 超音波ブラシとさまざまな商品が開発されているが, 使用 頻度はかなり低い。専門家の私たちはしっかりそれらの違 いや効果を認識し, 深い知識を持ち, 患者に的確な知識を 伝える必要がある。

「愛知県歯科医師会歯科需要調査」3)では, 説明が不十 分という設問の平均スコアは 5 段階中 3.18 というなか, 当 歯科医院では 4.69 という高い満足度を得られている。よっ て, 患者の希望を知り, 歯科医師・歯科衛生士の医学的意 味のある歯科治療・予防の動機付けをするためには，しっ かりコミュニケーションをはかり, 説明をきちんと行い, 信頼関係を築くことが大切だということがわかった。しか し，説明をしっかり行うということは，1 人にかかる時間 が長くなり, 待ち時間やアポイントの取り方に響いてきて おり, 来院してから診療室に入るまでのスコアが 3.79 と低 
くなっている。「愛知県歯科医師会歯科需要調査」でも, 待ち時間の設問のスコアは 2.56 とかなり低い。実際に「待 ち時間が長いのでなんとかしてほしい」「予約をもっと詰 めて取ってほしい」という意見はかなり多く，これが原因 で来院しなくなった患者もいる，このことから，医療が乱 立し，歯科医療サービスを考慮するなか，これらの不満点 に対して早急に対応し，顧客満足を向上させ，今後も定期

\section{参考文献}

1) 岩山幸雄：歯槽膿漏は歯ブラシで治そう. 医歯薬出版(東京), 1991.

2）荒川浩久：別冊歯科衛生士 プラークコントロールのための ホームケア指導. クインテッセンス出版 (東京), 2000 .
的に満足度調査を実施し，歯科医療サービスの向上に努め たい。また，好ましい歯科保健行動を知識としては理解し ているが，日常生活にまで反映されていないこの現状を改 善できるように，今後これらの調査結果を生かし，さらに 患者によりよい治療・ 口腔内管理, そして予防などに誘導 するように努めたい。

3）安川文朗：消費者は予防歯科をどう受け入れるか? 一予防 管理型歯科プログラムに対する消費者の選考分析結果一. 日本歯科医師会雑誌，55 (9)：1750-1763，2002. 